\title{
Shareholders' Wealth and Debt- Equity Mix of Quoted Companies in Nigeria
}

\author{
Amos O. Arowoshegbe ${ }^{1} \&$ Francis Kehinde Emeni $^{2}$ \\ ${ }^{1}$ Department of Accounting, Ambrose Alli University, Ekpoma, Edo State, Nigeria \\ ${ }^{2}$ Department of Accounting, University of Benin, Benin City, Edo State, Nigeria \\ Correspondence: Amos O. Arowoshegbe Ph.D; ACA., Department of Accounting, Ambrose Alli University, \\ Ekpoma, Edo State, Nigeria. Tel: 234-80-3742-2421. E-mail: futona4christ2@gmail.com
}

Received: October 15, 2013

doi:10.5430/ijfr.v5n1p107
Accepted: October 31, 2013

Online Published: January 10, 2014

URL: http://dx.doi.org/10.5430/ijfr.v5n1p107

\begin{abstract}
The study examined the relationship between shareholders' wealth and debt-equity mix of quoted companies in Nigeria. The study was based on a panel data set from 1997 to 2011 comprising sixty non - financial companies. The study specified two panel regression models. Two measures of shareholders' wealth: Return on Equity (ROE) and Earnings per Share (EPS) were taken as the dependent variables respectively. The principal explanatory variable for each of the models was Debt Ratio (DR). The results of the study conform to our a-priori expectation that there is a significant negative relationship between shareholders' wealth and debt-equity mix of quoted companies in Nigeria. This is not unexpected considering the inactive debt market in Nigeria, the dominance of the money market in the Nigerian financial system, the shallow nature of the Nigerian capital market, the buy-hold syndrome of the Nigerian investors and the macro economic instability in the country. It was recommended that adequate fiscal policies, relevant capital market institutional and legal framework should be put in place. These measures, we believe, will enhance the development of the Nigerian capital market and create a more conducive environment for business to thrive.
\end{abstract}

Keywords: capital structure, shareholders' wealth, earning per share, return on equity

\section{Introduction}

Half a century of research on capital structure attempted to verify the presence of an optimal capital structure that could amplify the company's ability to create value and invariably maximize the wealth of the shareholders. When companies decide on the use of debt finance, they are reallocating some expected future cash flows away from equity claimants in exchange for cash up-front. The factors that drive this decision remain elusive despite a vast theoretical literature, and despite decades of empirical tests.

The use of debt in the capital structure of the firm often leads to agency costs. The agency cost theory is premised on the idea that the interests of the company's managers and its shareholders are not perfectly aligned. Jensen and Meckling (1976) emphasize the importance of the agency costs of equity arising from the separation of ownership and control of firms whereby managers tend to maximize their own utility rather than the value of the firm. Agency costs can also exist from conflicts between debt and equity investors. These conflicts arise when there is a risk of default. The risk of default may create what Myers (1977) refers to as an "underinvestment" or "debts overhang" problem. In this case, debt will have a negative effect on the value of the firm. Alternatively, there may be instances where managers have incentives to take excessive risks as part of risk shifting investment strategies (Jensen and Meckling, 1976). This leads us to Jensen's (1986) "free cash flow theory" where as stated by Jensen (1986:323) "the problem is how to motivate managers to disgorge the cash rather than investing it below the cost of capital or wasting it on organizational inefficiencies." Thus high debt ratios may be used as a disciplinary device to reduce managerial cash flow waste through the threat of liquidation (Grossman and Hart, 1982) or through pressure to generate cash flows to service debt (Jensen, 1986). In these situations, debt will have a positive effect on the value of the firm. The maximization of shareholders' wealth is a function of the value of the firm. The objective of the study is to examine the relationship of the use of debt in the capital structure of quoted companies in Nigeria to the wealth of shareholders. 


\section{Literature Review}

Capital structure theories are concerned with explaining how the mix of debt and equity in a firm's capital structure influences its market value. The debt-equity mix has an overall implication for the shareholders' earnings and risk which in turn affects the cost of capital and financial performance of the company and invariably the wealth of the company. Since the seminal paper by Modigliani and Miller (1958) and their proposition that the value of the firm is independent of its debt - equity mix, two basic theories that have dominated the capital structure literature are the "trade-off theory" and the "pecking order theory".

Which theory shall we take seriously? Naturally, opinions differ. Many theories of capital structure have been proposed. But only a few seems to have many advocates. Notably, most corporate finance textbooks point to the "tradeoff theory" in which taxation and deadweight bankruptcy costs are key points. Myers (1984) proposed the "pecking order theory" in which there is a financing hierarchy of retained earnings, debt and then equity. Recently the idea that firms engage in "market timing" (that is, use equity finance when they believe it is undervalued and use debt when they believe equity is overvalued) has become popular. Finally, agency theory lurks in the background of much theoretical discussion. Agency concerns are often lumped into the tradeoff framework broadly interpreted. The bottom line of the various theories is to validate the determinants of capital structure and/or the relevance or otherwise of capital structure to firms' value.

The wealth of the shareholders of a firm is a reflection of the level of Return on Equity (ROE) and Earnings per Share (EPS) of that firm. Return on Equity shows the relationship between net profit after tax and net equity, that is, the capital plus all retentions and reserves. ROE indicates how well the firm has used the resources of shareholders. This ratio is one of the most important relationships in financial analysis. The earning of a satisfactory return implies the maximization of shareholders wealth. This is the most desirable objective of a business. This ratio reflects the extent to which this objective has been accomplished. Thus, this ratio is of great interest to the actual and potential share-holders and also of great concern to management, which has the responsibility of maximizing the shareholders' wealth. A firm can convert its ROA into an impressive ROE through financial efficiency. Financial leverage and debt-equity ratios affect ROE and reflect efficiency. ROE is thus a product of ROA (reflecting operating efficiency) and financial leverage ratios (reflecting financial efficiency).

Earning Per Share (EPS) is the measure of the profitability of the common shareholders' investment. It is defined by the relationship between profit after tax and the number of common (ordinary) shares outstanding. EPS simply shows the profitability of the firm on a per-share basis. As a profitability index, it is a valuable and widely used ratio (Pandey, 1999). Leverage magnifies the EPS for a firm with positive earnings. It is therefore a measure of shareholders' wealth.

\section{Methodology}

\subsection{Research Design}

The study covered a period of 15 years, that is, $1997-2011$. The population of the study was all the 134 non financial firms quoted on the Nigerian Stock Exchange as at 2011. The sample size was determined by using the Burley's formula for the determination of sample size for finite population as propounded by Yamane (1973). The formula is expressed as follows:

$$
\mathrm{n}=\frac{\mathrm{N}}{1+\mathrm{N}(\mathrm{e})^{2}}
$$

Where $\mathrm{n}=$ sample size

$$
\begin{aligned}
& \mathrm{N}=\text { Population } \\
& \mathrm{e}=\text { Level of significance }(5 \% \text { for this study) }
\end{aligned}
$$

This procedure produced a sample size of 100 firms. The selection of the 100 firms was based on stratified random sampling technique. The research population was organized into homogenous subsets with heterogeneity between the subsets in accordance with the Nigerian Stock Exchange sectoral classification as at 2011. From each sector, the sample companies were drawn randomly based on the relative proportion of the population represented by each sector. To achieve this, the names of the companies in each of the sectors were written on equal-sized pieces of paper one at a time. These pieces of paper were then kept in baskets - one for each sector - and an assistant was asked to pick a total of 100 pieces of paper from the baskets (with replacement) on the basis of the relative proportion of the population represented by each sector. This is to ensure proportional representation of the different sectors that make up the population. 
From this sample size, we deleted firms that do not have complete data of the relevant variables required for our analysis. This may be due to cessation of operation before 2011, commencement of operations after 1997, change of accounting year-end or problems with the Nigerian Stock Exchange and Securities and Exchange Commission at any point during the period of study. This measure helps to guide against data omission and ensure uniformity in data presentation. Thus, the study retained a sample size of sixty (60) firms over a fifteen (15) - year period of time in a balanced panel. These firms are active non-financial firms with a basic characteristic of continuous operational existence over a period of at least fifteen years to date.

\subsection{Source of Data Collection and Data Management}

The study relied wholly on secondary sources of data from where we collected data to calculate Capital Intensity (CI), Size (S), Debt Ratio (DR), Age (A), Current Ratio (CR), Total Assets Turnover (TAT), Return on Equity (ROE) and Earnings per Share (EPS), which were used for the analysis. Debt ratio, which is the ratio of total debts to total assets, was used as the principal explanatory variable in the study. It served as the proxy for capital structure. In order to recognize the fact that a number of factors associated with leverage may impact on performance, other variables were also chosen as explanatory variables and used in this study as control variables. These control variables were treated in the same way as the explanatory variable. The control variables that were used are total asset turnover, size, current ratio, age and capital intensity.

For the statistical analysis, first, we carried out descriptive analysis of data using correlation matrix and Jacque Bera test. This was to ascertain the pattern of relationship among the data and the possible degree of multi-colinearity among the regressors. The results obtained were satisfactory. Second, we carried out econometric analysis based on panel data regression techniques. To start with, we carried out a level ordinary least square analysis on the pooled data. And as was expected, the results were biased and spurious. To correct for this, we adopted the first difference autoregressive analysis. Because of the panel nature of the data, we carried out analysis based on both the fixed effect models and the random effect models. A comparison of the overall performance of the models indicated that the fixed effect models have better results. To confirm this, we carried out a Hauseman specification test of choice and the result confirmed the superiority of the fixed effect results over the random effect results. Hence our analysis was based on the fixed effect models.

\subsection{Model Specification}

The model in the form suitable for the empirical testing of the data was stated as:

$$
\begin{aligned}
R O E_{i t} & =\left(\alpha_{2}+\mu_{i 4}\right)+\beta_{1} D R_{i t}+\beta_{2} T A T_{i t}+\beta_{3} C R_{i t}+\beta_{4} A_{i t}+\beta_{5} S_{i t}-\beta_{6} C I_{i t}+V_{i t} \\
E P S_{i t} & =\left(\alpha_{2}+\mu_{i 3}\right)+\beta_{1} D R_{i t}+\beta_{2} T A T_{i t}+\beta_{3} C r_{i t}+\beta_{4} A_{i t}+\beta_{5} S_{i t}+\beta_{6} C I_{i t}+V_{i t}
\end{aligned}
$$

Where:

$$
\begin{aligned}
& \text { ROE = Return on Equity } \\
& \text { EPS = Earning per Share } \\
& \text { DR = Debt Ratio } \\
& \text { TAT = Total Asset Turnover } \\
& \text { CR = Current Ratio } \\
& \text { A = Age } \\
& \text { S = Size } \\
& \text { CI = Capital Intensity } \\
& \text { i ( }=1,2,3, \ldots 60) \text { is the given firm } \\
& \text { t = time } \\
& \text { Also, } \beta_{1}, \beta_{2}, \beta_{3}, \beta_{4}, \beta_{5}, \beta_{6}<0
\end{aligned}
$$

All the estimating procedures were programmed using E-Views 7.1 for windows.

\subsection{Research Hypothesis}

The research hypothesis tested was stated as:

Ho: There is no significant negative relationship between Shareholders' wealth and Debt-equity mix of quoted firms in Nigeria. 


\section{Data Analyses and Presentation of Results}

\subsection{Results and Analyses for Model 1}

Table 1. AR (1) results

Dependent variable is ROE.

\begin{tabular}{ccccc}
\hline Independent variables & Coefficients & Standard error & t-stat & Prob. \\
\hline C & -39.95073 & 51.80521 & -0.771172 & 0.4408 \\
DR & -53.39317 & 19.31198 & $-2.764769 * *$ & 0.0058 \\
TAT & 1.969635 & 3.241828 & 0.607569 & 0.5437 \\
CR & 0.046502 & 0.2201 & 0.211275 & 0.8327 \\
A & 1.995726 & 1.34565 & 1.483094 & 0.1385 \\
S & 0.06642 & 0.245311 & 0.270758 & 0.7867 \\
CI & -8.80456 & 12.66652 & -0.695105 & 0.4872 \\
AR(1) & -0.035558 & 0.036532 & -0.973331 & 0.3307 \\
\hline R - squared & 0.124537 & Mean dependent var & 8.091768 & \\
\hline Adjusted R - squared & 0.049662 & S.D dependent var & 147.0724 & \\
\hline S.E of regression & 143.3739 & Akaike info. Criterion & 12.8432 & \\
\hline Sum squared Resid. & 15622623 & Pool Observation & 826 \\
\hline F-statistic & 1.663265 & No of cross - section & 59 \\
\hline Inverted AR Roots & -0.04 & D.W - statistic & 2.13501 \\
\hline
\end{tabular}

Source: Author's computation (2013)

Note: **=significant @ $5 \%$

$$
\begin{aligned}
& \mathrm{ROE}=-39.95-53.40 \mathrm{DR}+1.97 \mathrm{TAT}+0.05 \mathrm{CR}+2.00 \mathrm{~A}+0.07 \mathrm{~S}-8.80 \mathrm{CI}
\end{aligned}
$$

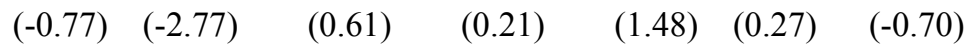

$$
\begin{aligned}
& \mathrm{R}^{2}=0.12 \\
& \text { Adj. } \mathrm{R}^{2}=0.05 \\
& \text { F-Stat. }=1.66
\end{aligned}
$$

From Table 1 above, it can be concluded from the adjusted $\mathrm{R}$ - squared value of 0.049662 that the independent variables together explain over $4.9 \%$ of the systematic variations in ROE during the period studied. The F-statistic of 1.663265 is not significant; it did not pass the significant test at the $1 \%$ level. Thus, there is no significant linear relationship between ROE and the six independent variables as a group. The signs of the coefficients are correct for DR and CI. The negative sign of DR and CI indicates that there is an inverse relationship between ROE and the variables while the positive sign of the coefficient of TAT, CR, A and S shows that there is a direct relationship between the variables and ROE. The t-values of $0.61,0.21,1.48,0.27$ and -0.70 for TAT, CR, A, S and CI respectively did not pass the two-tailed test of significance at the $1 \%$ level. However, the -53.39 coefficient of DR is significant at the 5 percent level with a t-value of -2.77 . This means that it is only DR among the independents variables that is capable of predicting ROE while the remaining variables can not. This generally asserts the position that of the capital structure terms, only debt ratio has a significant impact on profitability and invariably shareholders' wealth. Indeed, a firm's profitability tends to decline as its debt ratio rises. This is in line with the argument so far in the study. The t-value of the coefficient of AR(I) indicates that it did not pass the two-tailed test of significance of the $1 \%$ level which shows that there is the existence of autocorrelation problem. However, the D.W-statistic of 2.13501 and inverted AR roots of -0.04 indicates the absence of autocorrelation after correction. This implies that the estimates are reliable for structural analysis and policy direction.

In the next section, we present the result for model 2 using Earning per Share (EPS) - measure of shareholders' wealth- as dependent variable. 


\subsection{Results and Analyses for Model 2}

Table 2. AR (1) results

Dependent variable is EPS.

\begin{tabular}{|c|c|c|c|c|}
\hline Independent variables & Coefficients & Standard error & t-stat & Prob. \\
\hline $\mathrm{C}$ & -16.09622 & 72.31839 & -0.222574 & 0.8239 \\
\hline DR & -141.4747 & 19.29954 & $-7.330467 *$ & 0.0000 \\
\hline TAT & -3.326004 & 3.095969 & -1.073955 & 0.2832 \\
\hline $\mathrm{CR}$ & 0.04106 & 0.185522 & 0.221322 & 0.8249 \\
\hline A & 4.505075 & 1.837145 & $2.451671 * *$ & 0.0144 \\
\hline $\mathrm{S}$ & 2.161946 & 0.295245 & $7.322554^{*}$ & 0.0000 \\
\hline $\mathrm{CI}$ & -16.66404 & 11.5067 & -1.448203 & 0.148 \\
\hline $\operatorname{AR}(1)$ & 0.324889 & 0.036107 & $8.998048 *$ & 0.0000 \\
\hline $\mathrm{R}$ - squared & 0.701821 & Mean dependent var & \multicolumn{2}{|c|}{97.95413} \\
\hline Adjusted R - squared & 0.676319 & S.D dependent var & \multicolumn{2}{|c|}{228.8974} \\
\hline S.E of regression & 130.2265 & Akaike info. Criterion & \multicolumn{2}{|c|}{12.65296} \\
\hline Sum squared Resid. & 12888796 & Pool Observation & \multicolumn{2}{|c|}{826} \\
\hline F-statistic & 27.52012 & No of cross - section & \multicolumn{2}{|l|}{59} \\
\hline Inverted AR Roots & 0.32 & D.W - statistic & \multicolumn{2}{|c|}{2.076784} \\
\hline
\end{tabular}

Source: Author's computation (2013)

Note: $*=$ significant @ $1 \%$

$* *=$ significant $@ 5 \%$

$\mathrm{EPS}=-16.10-141.48 \mathrm{DR}-3.33 \mathrm{TAT}+0.04 \mathrm{CR}+4.51 \mathrm{~A}+2.16 \mathrm{~S}-16.66 \mathrm{CI}$

$(0.22)$

$(0.22)$

$(2.45)$

(7.32) (-1.45)

$\mathrm{R}^{2}=0.70$

Adj. $R^{2}=0.68$

F-Stat. $=27.52$

From Table 2, the value of the Adjusted R - squared shows that the six independent variables (DR, TAT, CR, A, S, $\& \mathrm{CI}$ ) together explain over $67 \%$ of the systematic variations in EPS during the period studied. The F-statistic of 27.52012 is significant, passing the significance test at the $1 \%$ level. Therefore, the hypothesis of a significant linear relationship is indicated as a group. The negative signs of the variables are correct except for CR, A and S which show positive signs. The negative signs of the coefficients of DR, TAT and CI show that there is an inverse relationship between EPS and the variables. This further revealed that an increase in EPS will lead to a decrease in DR, TAT and CI. This confirms the theoretical postulation that an increase in EPS will lead to a decrease in the variables. The positive signs of the coefficients of CR, A and S show that there is a direct relationship between EPS and the variables. The t-values of $-7.33,2.45$ and 7.32 for DR, A \& S pass the two-tailed test of significance at the $1 \%$ level. This means that DR, A and S respectively are capable of predicting EPS as a group while the remaining variables; TAT, CR, \& CI did not pass the significance test at $1 \%$ level. The implications of the results are that debt ratio significantly impairs a firm's EPS, while both age and size tend to improve it. The other capital structure variables do not significantly contribute in predicting the behaviour of a company's EPS. The t-value of autocorrelation test of -9.00 is significant at $1 \%$ level which means that there is absence of positive autocorrelation. This result is further supported by D.W-statistic and inverted AR roots results of 2.076784 and 0.32 respectively. These results show the absence of autocorrelation. This means that the estimates are reliable for structural analysis and policy direction. 


\section{Discussion of Findings}

It was hypothesized that Debt Ratio (DR) as a proxy of corporate leverage is negatively related to Earning per Share (EPS) and Return on Equity (ROE) as proxies of shareholders' wealth. As individual variable, the estimate of the relationship between Debt Ratio (DR) and Return on Equity (ROE) shows a negative relationship. This implies that an increase in debt ratio will bring about a decrease in return on equity. The t-value of debt ratio is significant at $1 \%$ level. This implies that debt ratio is capable of predicting return on equity and by implication shareholders' wealth. This significant negative relationship between debt ratio and return on equity conforms to the theoretical postulation and also the findings of Carter (1977); Onaolapo \& Kajola (2010); Ebaid (2009) and Ramakrishnan (2002). The result also indicates that all the five control variables used in the model are not capable of predicting corporate leverage of quoted companies in Nigeria.

The EPS regression result indicates that the explanatory variables together explain over $67 \%$ of the systematic variations in EPS during the period studied. As individual variable, the estimate of the relationship between Debt Ratio (DR) and Earning Per Share (EPS) shows a negative relationship. This implies that an increase in debt ratio will bring about a decrease in earning per share. The t-value of debt ratio is significant at $1 \%$ level. The implication of this result is that, debt ratio significantly impairs a firm's earning per share. This position conforms to the findings of Akintoye (2008); Rao, et al (2007) and Foo (2002); thus, supporting the pecking order theory. Indeed, debt-equity mix magnifies the EPS for a firm with positive earnings. At the same time, it magnifies the losses for a firm with negative earnings. Profitability is a measure of the earning power of a firm. The earning power of the firm is the basic concern of its owners.

The regression results of the two models discussed above clearly indicate that capital structure has a significant negative relationship with shareholders wealth. The advantage of issuing stocks rather than debts is that the firm will avoid the bankruptcy risks associated with debt financing. However, the disadvantage of issuing stocks is that it will lead to dilution in earnings per share (Rao, etal 2007). Equity and debt agency costs reduce firm value. To reduce these costs, managers can choose the least costly financial policy mix, trading off benefits and costs of personal stock ownership with benefits and costs of debt financing and with benefits and costs of paying dividends. In this way, management adopts a policy mix that is uniquely related to their firm's respective policy benefits and costs.

\section{Concluding Remarks}

The study examined the relationship between shareholders' wealth and debt-equity mix of quoted companies in Nigeria. The study conforms to our a-priori expectation that there is a significant negative relationship between shareholders' wealth and debt-equity mix of quoted companies in Nigeria. thus, supporting the pecking order theory. The pecking order theory posits that firms that are profitable and therefore generate high earnings are expected to use less debt capital than those that do not generate high earnings. The interpretation here is that the use of debt financing contributes negatively to the maximization of shareholders' wealth.

A noticeable feature of business firms in Nigeria was the over-reliance on the money market for their funds requirements. Most business firms in Nigeria have not increased their equity share capital by way of public issue since their first public issue of shares at inception. Thus, there is the possibility that they use short-term funds to finance some of their long-term projects and this is contrary to the position in the Finance Literature. The study observed that instead of issuing new equity shares to raise funds; they rely on their retained earnings and short-term bank loans. The fear of raising equity shares from the capital market may be due to the high transaction costs and other developmental problems inherent in the Nigerian capital market. The study therefore recommends that government should consider it an urgent imperative to free the Nigerian capital market from the structures of irrelevant regulation; ensure greater transparency and deepening of the market. The study also recommends that there should be a reduction in the transaction costs in the Nigerian capital market. This can be achieved by decreasing the intermediation costs by eliminating stamp duties, reducing list fees, reducing brokers and dealers' registration fees and annual subscription; and deregulating dealers' commission. These measures will provide incentives for companies to issue more equity capital, and enhance growth in the primary capital market.

\section{References}

Akintoye, I. R. (2008). Effect of capital experience on firms' performance: The Nigerian experience. European Journal of Economics, Finance and Administrative Sciences, 10, 162-170.

Carter, J. R. (1977). The search for synergy: A structure performance test. Review of Economic and Statistics, 59, 279-289. http://dx.doi.org/10.2307/1925046 
Ebaid, I. E. (2009). The impact of capital structure choice on firm performance: Empirical evidence from Egypt. The Journal of Risk Finance, 10(5), 477-487. http://dx.doi.org/10.1108/15265940911001385

Foo, S. M. (2002). An investigation of the relationship between capital structure and corporate performance in the trading/services and plantation sector. (Unpublished master's thesis). Multimedia University, Kuala Lumpur, Malaysia.

Grossman, S. J., \& Hart, O. (1982). Corporate Financial Structure and Managerial Incentives. In J. McCall (Ed.), The Economics of information and uncertainty (pp. 107-40). Chicago: University of Chicago Press.

Jensen, M. C. (1986). Agency cost of free cash flow, corporate finance and takeovers. American Economic Review, 76, 323-329.

Jensen, M. C., \& Meckling, W. H. (1976). Theory of the firm: Managerial behaviour, agency cost and ownership structure. Journal of Financial Economics, 3, 305-360. http://dx.doi.org/10.1016/0304-405X(76)90026-X

Modigliani, F., \& Miller, M. H. (1958). The cost of capital, corporation finance, and the theory of investment. American Economic review, 48, 261-297.

Myers, S. C. (1977). Determinant of corporate borrowing. Journal of Financial Economics, 5, 147-175. http://dx.doi.org/10.1016/0304-405X(77)90015-0

Myers, S. C. (1984). The capital structure puzzle. Journal of Finance, 39(3), 575-592. http://dx.doi.org/10.2307/2327916

Onaolapo, A. A., \& Kajola, S. O. (2010). Capital structure and firm performance: evidence from Nigeria. European Journal of Economics, Finance and Administrative Sciences, 25, 43-51.

Pandey, I. M. (1999). Financial management. New Delhi, India: Vikas Publishing House.

Ramakrishnan, S. (2002). An investigation of the relationship between capital structure and corporate performance of firms in the financial and consumer product sector during and after financial crisis. (Unpublished MBA Thesis). University of Putra, Putra, Malaysia.

Rao, N. V., Al-Yahyaee, K. H. M., \& Syeed L. A. M. (2007). Capital structure and financial performance: Evidence from Oman. Indian Journal of Economics and Business, 6(1), 1-23.

Yamane, Y. (1973). Statistics: An introductory analysis ( $3^{\text {rd }}$ ed.). New York, NY: Harper \& Row. 